\title{
1960年代に実施された「西日本都市診断」の 内容分析およびその都市政策的影響
}

\author{
筒井 正幸 1 - 石橋 知也2 \\ 1学生会員 長崎大学大学院博士前期課程 工学研究科（†852-8521 長崎県長崎市文教町1-14) \\ E-mail: bb52118505@ms.nagasaki-u.ac.jp \\ 2正会員 長崎大学大学院准教授 工学研究科（†852-8521 長崎県長崎市文教町1-14） \\ E-mail: itomoya@nagasaki-u.ac.jp
}

\begin{abstract}
本研究では，1962-65年に都市系の専門家の協力のもと西日本新聞社によって実施された「西日本都市 診断」の内容に着目し, 診断された21都市のうち9都市を事例に, 各都市の診断の要点を整理したうえで, 往時の都市診断の議論やその後の都市政策に及ぼした影響について考察することを目的とする. その結果， 1960年代の計画にかかわる議論における西日本都市診断の位置づけとして全総や総合計画における論点を

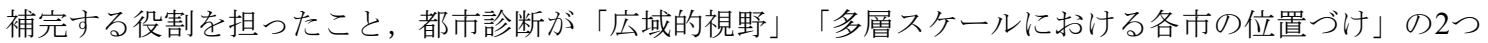
の特徵を有すること，を指摘した．診断委員と総合計画審議委員の重複や内容の類似点等についての分析 から往時の新聞という媒体のもつ都市政策への影響を指摘した．都市診断が総合計画を策定するための 「参考資料」の役割を担ったことも指摘した。
\end{abstract}

Key Words : urban diagnosis, urban policy, Kyushu and Yamaguchi region, 1960s, The Nishinippon Shimbun Co., Ltd.

\section{1. はじめに}

\section{(1) 研究の背景・目的}

人口減少時代のもと, 社会基盤施設も老朽化するなか, 各基礎自治体は自らの都市の将来像を模索するため都市 政策の検討を重初ているものの，具体的な将来像の模索 方法や政策検討の留意点についての知見の蓄積は未だ少 なく，政策検討の現場での課題となっている．例えば, 総合計画等の長期的な計画においては構想的な面が強く 不確定ななか策定されることを見込まざるを得ず，その 道筋を明確化するために各市の情勢への洞察や人々の価 值観等のモニタリング等を提示するといったことが政策 検討の現場での課題として挙げられる

一方で，都市計画家の莀原敬氏は，「1960年代の志を 顧夕て, それ以降の歴史を振り返り, 次の50年に備える 志と展望を持つことが強く求められている」2)と指摘し ており，1960年代の議論にはこれから50年後の都市像を 模索するうえでの手掛かりが含まれており，重要な示唆 を与えるものである.

加えて1960年代は，1962年に全国総合開発計画（以下， 全総），1969年に新全国総合開発計画が策定され，1969 年の地方自治法の改正に伴って基礎自治体における「総
合計画（基本構想）」の策定の義務化が謳われるなど， 国土計画の骨格となる都市政策の方針や基礎自治体にお ける都市像が検討され始めた時期と位置付けられる.こ のような時期と符号寸るかたちで，1962から65年にかけ て都市系の専門家の協力のもと, 西日本新聞社は「西日 本都市診断」という企画を実施している．しかしながら， 都市政策を扱う学術分野において，1960年代の計画にか かわる議論のなかで「西日本都市診断」がどのように位 置づくかについてはこれまで論じられてこなかった.

上記問題意識に基づき, 先述の「西日本都市診断」の 内容に着目し, 診断対象となった21都市（福岡市・北九 州市・田川市・ 山田市・ 甘木市・佐賀市・鳥栖市・唐津 市・長崎市・島原市・佐世保市・熊本市・八代市・鹿児 島市・ 川内市 - 日向延岡市 都城市 - 日田市 別府市 . 下関市・徳山市，名称は診断時のままで記載）のうち, 本研究では九州山口地方の各県から9都市（福岡市・北 九州市・佐賀市 - 長崎市 - 熊本市 鹿児島市・都城市 . 日田市・下関市）をケーススタディとして取り上げた.

なお，対象地の選定根拠として，九州地方を総合的に 把握するため全ての県から1つ以上の都市を選定するこ とを基本としつつ, 次の点に留意した. まず, のちに政 令市となった北九州市と福岡市は取り上げることを必須 
とした. 次に, 往時の人口規模および県庁所在地である か㧵かを勘案し，熊本市，長崎市，鹿児島市，佐賀市を 選定し，山口県に関しては診断対象の都市の中で人口規 模が最大の下関市を取り上げた. さらに，大分県におい ては，別府市は観光都市としての特徵を有しており既に 選出した長崎市や鹿児島市との類似性があるため, 異な る視点を得ることを念頭に近世城下町を起源とする日田 市を選定することとした. 加えて, 宮崎県においては, 日向・延岡市はのちに新産業都市に指定される等の特徵 はあるものの, 都城市は農業から工業への転換を図ろう としたことや人口規模が比較的少ないことの特徵が他の 8都市とは異なっていたため, 都城市を今回の研究対象 として選定した.

本研究では, 各都市における診断の要点を整理したう えで, 往時の都市診断において何が議論され，それらの 診断がその後の各市総合計画にみられる都市政策に及ぼ した影響について分析することを通して，都市診断の特 徵ならびにその役割について考察すること，加えて1960 年代の計画における位置づけについて明らかにすること, これらが本研究の目的である.

\section{(2) 研究の進め方}

本研究は次の手順で進めた。 まず, 西日本新聞社によ って報じられた「西日本都市診断」の記事)を収集し, 1966年に発刊された「都市診断西日本篇」4)を用いて補 完しながら，西日本都市診断の概要を整理した（2章）。 次に, 診断結果の内容を精読し, その要点を抽出した

(3章)。さらに，都市診断のその後の都市政策的影響 を把握するために，診断後に各都市で策定された総合計 画における記述内容と診断結果との比較をおこなった （4章）。以上を踏まえて, 都市診断の特徽ならびにそ の役割について考察をおこなった（5章）。

\section{(3) 既往研究と本研究の位置づけ}

本研究は都市政策を巡る史的考察を主眼としており, それに関連する既往研究についていくつかの観点で整理 する. まず，全国総合開発計画に関連するものとして， 国土計画に関する国会議事録における言説と全国総合開 発計画との比較によって今後の国土計画の役割について 考察した佐野・十代田の研究5が認められる. 次に, 総 合計画を対象とした研究では, 政令指定都市で策定され た総合計画に基づき副都心の施策上の位置付けや整備の 考え方について総合的に考察した三上・坂本の研究をを 始め, 福原・鈴木の地方自治体における政策形成の実 態・現状を総合計画の策定過程から考察した研究》が存 在する.さらに, 新聞資料を対象とした研究では, 田 中・藤井のマスメディアが公共事業に与える影響に着目 した研究8)始め, 原口らの明治期に行われた小樽港防
波堤埋立事業と水面埋立事業の相互の影響を新聞資料か ら考察した研究9)等が存在する.

一方で，石橋・柴田 ${ }^{10}$ は福岡市の1960年代の都市政策 の転換に着眼し，第一次および第二次の総合計画の内容 比較ならびに本研究で対象とする西日本都市診断の福岡 市に関する内容とを照査することによって，その転換の 経緯を明らかにしたうえで都市戦略のあり方について論 じている. 既往研究においては上記研究を除き, 西日本 都市診断そのものを研究対象としたものは管見の限り認 められない. 加えて, 西日本都市診断がその後の都市政 策に与えた影響について1960年代から70年代にかけて策 定された総合計画の内容分析から論じる点において, 先 述した関連の既往研究とは一線を画するものである.

\section{1960年代の計画にかかわる議論と西日本都市 診断の概要}

\section{(1) 1960年代の計画にかかわる議論}

ここでは，都市診断の実施された1960年代になされた 国土や基礎自治体にかかわる議論について述べる. 具体 的には，1962年策定の全国総合開発計画と1969年地方自 治法改正で義務付けられた基礎自治体における総合計画 の概要に触れながら, 既往研究等における論点について 整理する.

\section{a) 全国総合開発計画}

当時の日本では, 高度成長期への移行や過大都市問題, 所得格差の拡大, 所得倍増計画などが背景としてあり. この全総では地域間の均衡ある発展を目標としていた。

しかし，全総を「構想としての戦略」ととらえ「国土 計画は長期的，広域的な計画であるが故に不確定性を除 去することが出来ないもの」との指摘 ${ }^{11}$ が把握された.

\section{b) 総合計画}

地方自治法の改正により策定の義務化がなされた総合 計画は各都道府県や各市区町村が独自に定めるものであ る ${ }^{12}$. 自治体によって異なるが基本的には, 経済発展や 環境保護, 河川や交通や防災等の土木計画関連のものに 教育や福祉等を加えた総合的な計画となっており, 上位 計画との整合を加味しつつ策定される.

一方で福原は「各自治体の策定する計画はどの計画も 画一的でそれぞれ地域問題に即した内容に成り得てこな かった. 計画は, 地域における予算獲得や事業推進の指 針にすぎないのではないか，さらには本当に総合計画は 必要なのかという指摘もある」と言及している13).

\section{(2) 西日本都市診断の構成}

西日本都市診断とは，西日本新聞社が1962年に創刊85 周年を迎えた記念に実施した企画である ${ }^{14}$ ．社外の土木， 
地理学, 都市計画, 建築, 都市経営の専門家で構成され た委員により，前述の21都市が診断されている．1962年 4月の鹿児島を皮切りに約月一回のペースで新聞記事と して報じられた（図-1）。当時の担当記者へのヒアリン グより「当時は高度経済成長の真つ直中にあり，このま ま第二次産業中心の考え方で進んでよいものかという疑 問があった.さらに，モータリゼーションの影響で社会 生活, 産業構造の予測がつかず都市計画が不十分であっ たことから，広域圈における地域の位置づけについて考 えるため，西日本新聞社・経済部が中心となって委員会 を立ち上げた」との経緯を把握している.

診断内容は, 都市の素顔, 診断結果, 都市の性格・未 来図，産業，市民の生活等の項目について言及され，そ れらの課題や対策について記載がなされている．都市ご とに診断記事の分量は異なるが，総論としての診断結果

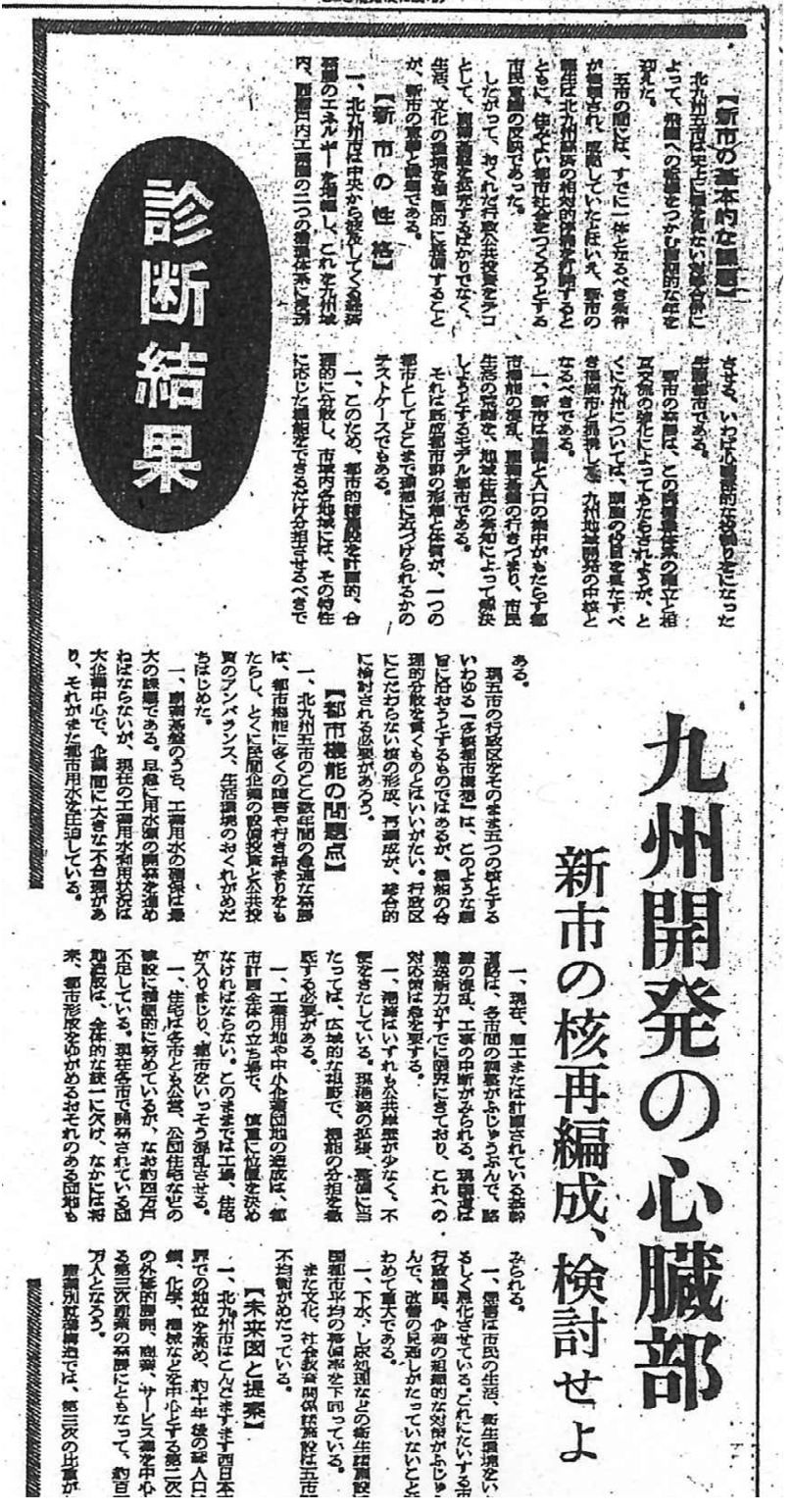

図-1 西日本都市診断記事の例（北九州市）
を第一報とし，その後各論を展開する構成をとり，おお むね4日間から7日間にわたる連載となっていることが特 徵である.さらに, 連載の締めくくりとして, 市長等と の対談記事も掲載されている場合も把握された.

\section{(3) 西日本都市診断の全体像}

ここでは，西日本都市診断の全体像を把握するために， 前述の「都市診断西日本篇」における「総論／西日本地 区の現状と展望」15)精読し，その要点を整理した（表1）、特筆すべき点について以下に述べる．第一章では, 診断の対象として取り扱った西日本地区の風土について, 文化や芸術，さらには都市ごとの気風について言及し， 九州内でも都市ごとの性格が異なることが指摘されてい る. 第二章では, 都市診断のなかでも中心的な論点であ つた産業構造について触れ，特に鉱業を中心とした製造 工業が後退し，新たに観光を中心とした第三次産業が九 州全体を牽引していることが指摘される．また，新たな 工業や商業の拠点，水資源開発にかかわる広域的な連携， 経済的なまとまりとしての九州像等について言及されて いる. さらに, マスタープラン（往時は現在の総合計画 をマスタープランと呼んでおり, 本研究では往時の新聞 記事での表現をそのまま用いた）の策定準備が遅れてい る状況を課題として挙げつつも, 一方で都市診断が九州 および中国地方の開発計画や新産業都市および工業整備 特別地域の計画の策定に寄与したことを指摘している.

また，「都市診断西日本篇」の「序」10で内藤は「わ れわれが，はじめてこの仕事に参加したころは，都市問 題もいまほど切実ではなかった。 なるほど政府の地域開 発計画は発表されていたし，そのなかでの都市の役割に ついても，大筋は示されていた，が，それはきわめて大 まかな構想にすぎず，しかもこの政府構想には幾通りの ものがあって地元の都市としては，実はその去就に迷っ ていた，というのが本音ではなかったかと思う」と当時 の地域開発計画の問題点を指摘している.

\section{（4） 21都市の都市診断の概要}

都市診断の掲載項目と各都市との関係を表-2に示寸. これより「まえがき」「素顔」「診断結果」「産業」に ついては全ての都市で言及されていることがわかる。こ のなかでも, 本研究では都市間の比較をおこなうため, 総論的かつ網羅的な内容を含んでいることから「診断結 果」という項目に着目して分析を進める.

\section{3.「診断結果」の内容分析}

\section{(1) 分析方法}

収集した新聞記事に記載された「診断結果」を精読し, 
表-1「総論／西日本地区の現状と展望」の要点

\begin{tabular}{|c|c|c|c|}
\hline まえがき & $\begin{array}{l}\text { 第二章 前進と後退の波一変容 } \\
\text { する西日本地区一 }\end{array}$ & （第二章） & （第: \\
\hline ·経済の高度成長は西日A & \multirow{51}{*}{ 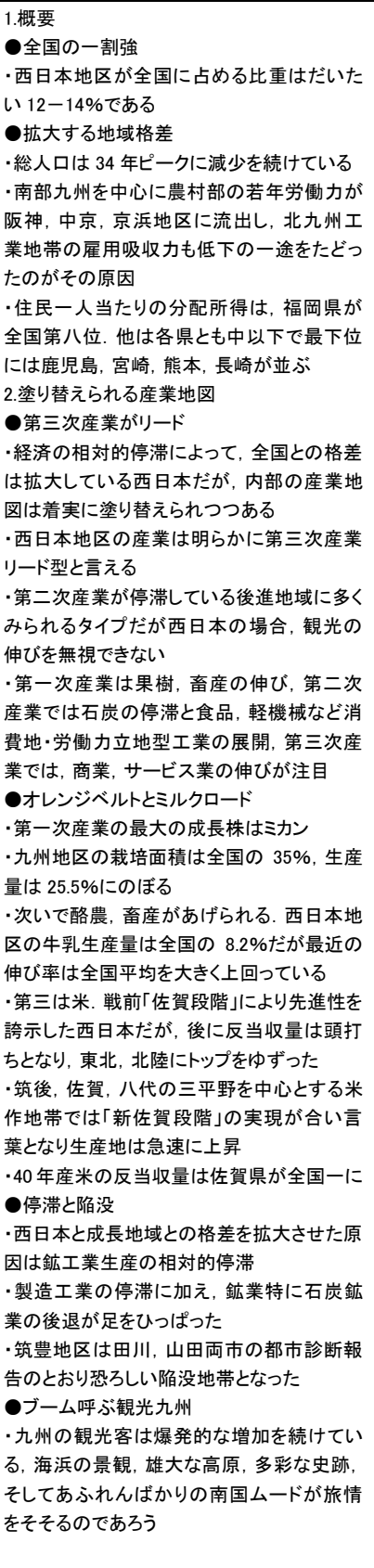 } & \multirow{51}{*}{ 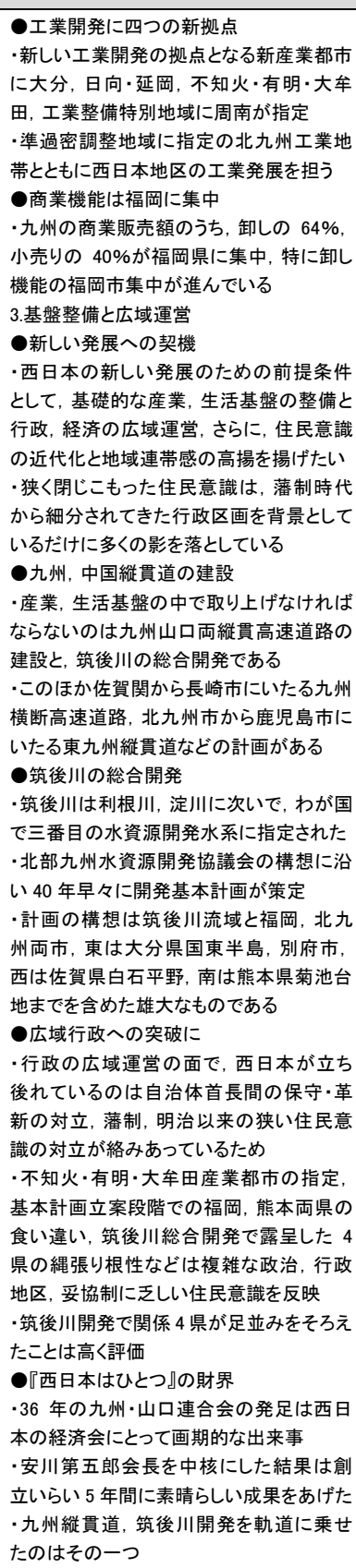 } & \multirow{51}{*}{ 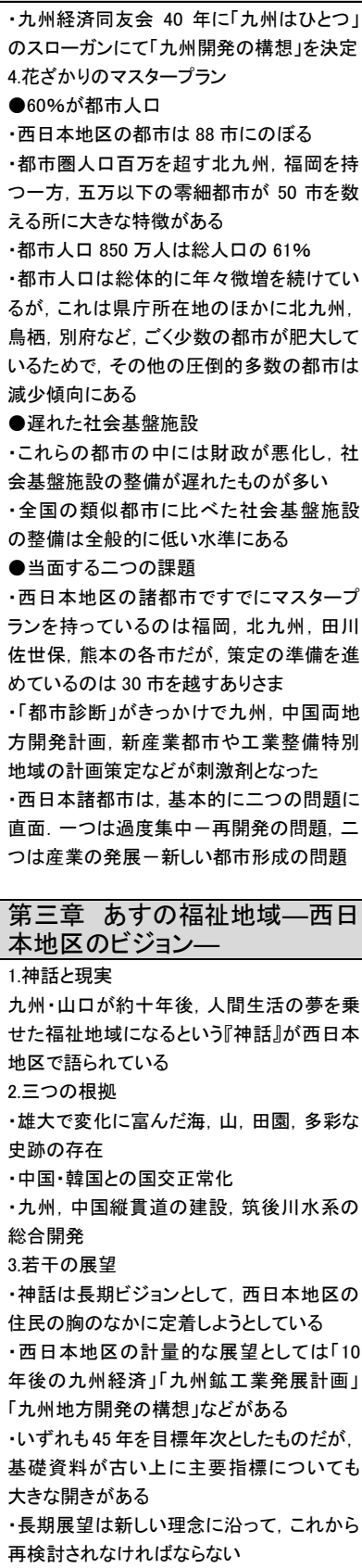 } \\
\hline & & & \\
\hline ・エネルギー & & & \\
\hline は，産業構造 & & & \\
\hline ·美し & & & \\
\hline にあたつて五 & & & \\
\hline ·基礎的産業 & & & \\
\hline ·日中韓の国 & & & \\
\hline 本地区 & & & \\
\hline & & & \\
\hline & & & \\
\hline 第一章 美 & & & \\
\hline & & & \\
\hline 1.光りは西方より & & & \\
\hline ·美しい自然 & & & \\
\hline の歴史と文化遗 & & & \\
\hline ·外来文化の輸 & & & \\
\hline פ方より”で近世 & & & \\
\hline ·考古学の出土 & & & \\
\hline けて農耕文化か & & & \\
\hline ·交易で栄華を言 & & & \\
\hline を文化の後 & & & \\
\hline エ業をおこした & & & \\
\hline られる大友宗鱗 & & & \\
\hline 興味を示した鍋 & & & \\
\hline で先進のエネル & & & \\
\hline 2.陶器と画家の & & & \\
\hline ·文化を古い伝統的 & & & \\
\hline に象徵される新 & & & \\
\hline $\begin{array}{l}\text { 日本では前者は } \\
\text {.伝統的なものの }\end{array}$ & & & \\
\hline $\begin{array}{l}\cdot \text { 明治以降の中 } \\
\text { 文化の衰退の }\end{array}$ & & & \\
\hline & & & \\
\hline 流出は激しく中 & & & \\
\hline ·西日本地区 & & & \\
\hline 都市型文化 0 & & & \\
\hline 3.開放的だがれ & & & \\
\hline ·半年雪に埋も & & & \\
\hline でねはり強し & & & \\
\hline ねはりが不足というのが足說 & & & \\
\hline ·早くから海外 & & & \\
\hline として発展した & & & \\
\hline ·急速な発展で異郷者が入った北九州，佐 & & & \\
\hline 世保などは市瓦 & & & \\
\hline ·安正した雄 & & & \\
\hline யபா & & & \\
\hline & & & \\
\hline 土，噮境とも & & & \\
\hline 时 & & & \\
\hline 巾ेटし C & & & \\
\hline & & & \\
\hline $\begin{array}{l}\text { 低所得地帝の忠循環を㙼大させる } \\
\text { なっていると指摘している人もいる }\end{array}$ & & & \\
\hline
\end{tabular}

その要点を抽出した．なお，未だ新聞記事の収集ができ ていない佐賀市に関しては「都市診断西日本篇」に記載 された内容で補完している ${ }^{17)}$.9都市の要点の抜粋につ いて表-3に示す.

\section{(2)「診断結果」とその根拠の示し方}

「診断結果」の中では，しばしば「べき論」が記載さ れるが，その診断結果を根拠として補完する新聞記事を 確認している.
例えば長崎市では「市は海に依存してきた海港都市で 経済, 文化の陸揚げ基地. 内陸へ展開すべき転換期だ. 大村, 諫早市など広域の都市づくりが必要で, 市は中核 的な役割を果たさねばならない」という記述の根拠とし て「自然条件に恵まれている長崎港も最大の弱点は背後 に大きな生産，消費地を持たないことだ．端的に言えば， 長崎は海と陸の交通の接点であり, 通過基地の役割を果 たしていたにすぎない．航空機が遠距離旅客輸送に圧倒 的な比重を占め貿易港が生産, 消費地立地の傾向を強め 
表-2 都市診断の掲載項目と 21 都市との関係

\begin{tabular}{|c|c|c|c|c|c|c|c|c|c|c|c|c|c|c|c|c|c|c|c|c|c|}
\hline $\begin{array}{l}\text { 診断された } \\
\text { 21都市 } \\
\text { 各都市 } \\
\text { の掲載項目 }\end{array}$ & $\begin{array}{l}\text { 福 } \\
\text { 岗 } \\
\text { 市 }\end{array}$ & $\begin{array}{l}\text { 北 } \\
\text { 州 } \\
\text { 市 }\end{array}$ & $\begin{array}{l}\text { 堶 } \\
\text { 賏 }\end{array}$ & $\begin{array}{l}\text { 長 } \\
\text { 崎 } \\
\text { 市 }\end{array}$ & $\begin{array}{l}\text { 熊 } \\
\text { 市 }\end{array}$ & $\begin{array}{l}\text { 鹿 } \\
\text { 島 } \\
\text { 市 }\end{array}$ & $\begin{array}{l}\text { 都 } \\
\text { 城 } \\
\text { 市 }\end{array}$ & $\begin{array}{l}\text { 早 } \\
\text { 男 }\end{array}$ & $\begin{array}{l}\text { 下 } \\
\text { 関 } \\
\text { 市 }\end{array}$ & $\begin{array}{l}\text { 思 } \\
\text { 市 } \\
\text { 市 }\end{array}$ & $\begin{array}{l}\text { 崮 } \\
\text { 市 }\end{array}$ & $\begin{array}{l}甘 \\
\text { 某 } \\
\text { 市 }\end{array}$ & $\begin{array}{l}\text { 鳥 } \\
\text { 栖 } \\
\text { 市 }\end{array}$ & $\begin{array}{l}\text { 唐 } \\
\text { 津 } \\
\text { 市 }\end{array}$ & $\begin{array}{l}\text { 島 } \\
\text { 原 } \\
\text { 市 }\end{array}$ & $\begin{array}{l}\text { 佐 } \\
\text { 世 } \\
\text { 保 } \\
\text { 市 }\end{array}$ & $\begin{array}{l}\text { 全 } \\
\text { 市 }\end{array}$ & $\begin{array}{l}\text { 川 } \\
\text { 内 } \\
\text { 市 }\end{array}$ & $\begin{array}{l}\text { 延日 } \\
\text { 岡向 } \\
\text { 市. }\end{array}$ & $\begin{array}{l}\text { 別 } \\
\text { 府 } \\
\text { 市 }\end{array}$ & $\begin{array}{l}\text { 德 } \\
\text { 市 }\end{array}$ \\
\hline まえがき & 0 & 0 & 0 & 0 & 0 & 0 & 0 & 0 & 0 & 0 & 0 & 0 & 0 & 0 & 0 & 0 & ○ & 0 & 0 & 0 & 0 \\
\hline 素顔 & 0 & 0 & 0 & 0 & 0 & 0 & 0 & 0 & 0 & 0 & 0 & 0 & 0 & 0 & 0 & 0 & 0 & 0 & 0 & 0 & 0 \\
\hline 診断結果 & 0 & 0 & 0 & 0 & 0 & 0 & 0 & 0 & 0 & 0 & 0 & 0 & 0 & 0 & 0 & 0 & 0 & 0 & 0 & 0 & 0 \\
\hline 性格と未来図 & & 0 & 0 & 0 & 0 & & 0 & 0 & 0 & 0 & 0 & 0 & 0 & 0 & 0 & 0 & 0 & & 0 & 0 & 0 \\
\hline 観光 & & & & & & & & & & & & & & 0 & 0 & & & & & 0 & \\
\hline 都市形成 & & & 0 & & & & & & & & & & & 0 & & & & & & & \\
\hline 市の性格 & 0 & & & & & 0 & & & & & & & & & & & & 0 & & & \\
\hline 第一次産業 & 0 & 0 & 0 & 0 & 0 & \multirow{10}{*}{0} & 0 & 0 & 0 & 0 & 0 & 0 & 0 & \multirow{3}{*}{0} & 0 & 0 & 0 & 0 & 0 & \multirow{3}{*}{ O } & 0 \\
\hline 第二次産業 & 0 & 0 & 0 & 0 & 0 & & 0 & 0 & 0 & & 0 & 0 & 0 & & 0 & 0 & 0 & 0 & 0 & & 0 \\
\hline 第三次産業 & 0 & 0 & 0 & 0 & 0 & & 0 & 0 & 0 & 0 & 0 & 0 & 0 & & 0 & 0 & 0 & 0 & 0 & & 0 \\
\hline 産岸地振興 & & & & & & & & & & 0 & 0 & & & & & & & & & & \\
\hline 工・鉱業 & & & & & & & & & & 0 & & & & & & & & & & & \\
\hline 産業基盤（上） & 0 & 0 & 0 & 0 & 0 & & 0 & 0 & 0 & & & 0 & 0 & 0 & 0 & 0 & $\circ$ & 0 & 0 & 0 & 0 \\
\hline 産業基盤（下） & $\circ$ & 0 & & & & & & & & & & & & & & & & & & & \\
\hline 生活基盤（上） & 0 & 0 & 0 & 0 & & & 0 & 0 & & & 0 & 0 & 0 & 0 & 0 & & 0 & 0 & 0 & 0 & \multirow{3}{*}{0} \\
\hline 生活基盤（下） & & 0 & & & & & & & & & & & & & & & & & & & \\
\hline 生活· 文化 & & & & & 0 & & & & 0 & 0 & & & & & & 0 & & & & & \\
\hline 結U & 0 & & & & & O & & & & & & & & & & & & & & & \\
\hline
\end{tabular}

るにつれ長崎の優位はくずれた。（中略）いっぽう，造 船, 水産業は世界船舶需要の見通し, 水産業の発展方向 などからみて，こんご日本経済の成長をリードするほど 大きく伸びるとは考えられず，長崎市発展の原動力を従 来の三つの柱（造船，水産，貿易）だけに頼ることは適 当でないと判断した」とある.

このように，診断結果全体にわたり，第一報記事とし ての結論とそれを補完する根拠の記事という構造で連載 されており，表-3には第一報記事の要約を示しているが, 全体にわたりその根拠が裏付けられていることを把握し ている.

\section{(3) 得られた要点}

ここでは，表-3でまとめた内容から得られた要点を 4 つに整理し, 以下に示寸.

\section{a) 地域資源の活用}

例えば鹿児島市では「市と周辺は観光地として脚光を 浴びはじめた．問題は多いが観光都市として発展を目指 すことは妥当」「工業開発の方向は，食品，木材加工な ど資源加工業を中心に製造工業の芽生えと発展に期待, 重化学工業の誘致は長期的な場合, 重化学工業が立地す る可能性あり」，都城市では「霧島酪農地帯が背景の畜 産加工，流通発展を求めるべき，資源型，労働集約型工 業を育成し厚い工業生産都市を目指寸べき」との記述を 得た. これらのことから診断結果の要点として「地域資 源の活用」を挙げた.

\section{b) 産業とインフラの結びつき}

例えば長崎市では「第三次産業発展のため商業区の拡 大，高層化，駐車場の整備など再開発を進め交通網を整 え，周辺購買力吸収の努力が大切．観光については何を 資源とし振興するか意見調整が先決」，鹿児島市では
「市が南九州の拠点都市であるために，地方諸都市と北 九州とを結ぶ輸送施設，整備が先決」との記述が得られ た.これらのことから診断結果の要点として「産業とイ ンフラの結びつき」を挙げた.

\section{c) 広域的視野}

例えば福岡市では「市は第二次産業を主軸とした産業 都市となるより，金融，商工，交通，政治，行政，文化， 教育等の内容と施設を充実し周辺都市群の機能を総合す べき」，熊本市では「市は有明工業地帯と八代臨海工業 地帯という異質な両工業地帯の接着剤となり不知火・有 明・大牟田新産都市を九州西海岸の新しい開発拠点に育 成しなければならない」との内容を抽出した。これらの ことから診断結果の要点として「広域的視野」を挙げた。

\section{d）多層スケールにおける都市の位置づけ}

例えば福岡市では「九州地域全体を統括し，その開発 と向上を助成する広域管理都市となるべき」，熊本市で は「市は北九州と南九州の経済連関を強化する中継地点 の役割を果たすべき」との記述が得られた．これらのこ とから診断結果の要点として「多層スケールにおける都 市の位置づけ」を挙げた.

\section{（4）特筆すべき要点の内容}

ここでは，前述した分析方法によって得られた要点の うち，特筆すべき内容について述べる.

\section{a) 広域的視野について}

前節c)に加え，長崎市では「住宅などの用地確保は現 在の市行政区画内に求めるより広域的に求めるべき」

「第二次産業の発展は内陸部への展開を中核とし，食料 品加工および中小造船など企業間の協力を進めるべき」, 鹿児島市では「市の観光資源に留まらず桜島，霧島，指 宿等を含む『結合観光』の考えが重要」との記述を得た. 
表-3 九州山口地方の主要 9都市の診断結果の要点

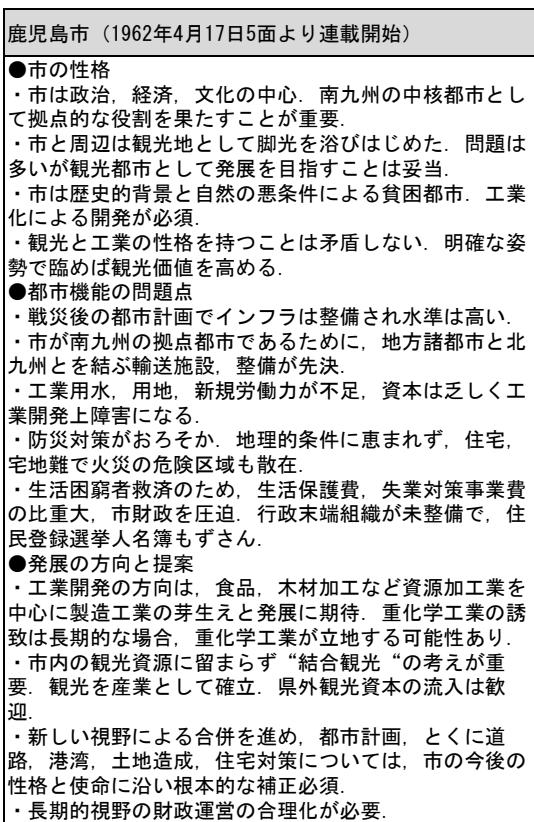

・長期的視野の財政運営の合理化が必要.
長崎市（1962年7月6日7面より連載開始）

当面の基本問題

土地, 水に恵まれない長崎市の課題は発展方向を明確に ，市民の協力を得た開発と再開発。

市の性格

・市は海に依存してきた海港都市で経済，文化の陸揚げ 基地. 内陸へ展開すべき転換期だ。大村, 諫早市など広 域の都市づくりが必要で，市は中核的な役割を果たさね ばならない。

・広域都市は既存の造船などを軸に第二次産業の育成に 期待. 市は観光を含めた第三次産業に期待。

・生活環境に重点を置いた都市づくりを提案。

都市機能の問題点

·鉄道の輸送力はすでに限界.九州横断自動車道路，長 崎バイパス，国道三十四号線の設備整備を急ぐべき ・都市計画は戦後復興が重点で将来構想が不明確なため 一貫性に久ける点が多い

- 過度密集地帯の再開発は防災上からもきわめて重要な 問題.

未来図と提案

- 第三次産業発展のため商業区の拡大，高層化，駐車場 の整備など再開発を進め交通網を整え，周辺購買力吸収 の努力が大切. 観光については何を資源とし振興するか 意見調整が先決

- 第二次産業の発展は内陸部への展開を中核都市, 食料

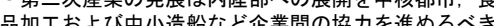
品加工およひ中小造船など企莱間の協力を進めるべき および水産業の賃金体系整備に努める必要がある。

\section{福岡市（1962年8月29日8面より連載開始）}

市の基本的な課題

市の課題は内部エネルギーを引き出し，九州における主 導力を強化するかにある

の市の今後の性格

・自らが第二次産業主軸の産業都市となるより，周辺都 市群の機能を総合すべき

- 九州地域全体を統括し，その開発と向上を助成する広 域管理都市となるべき

都市機能の問題点

整備・開発計画においてズレあり

ママスタープランは行政区にとらわれ広域的な視野の展 開に乏しい. 三次産業の構成比率の低さにより，事業計 画も大規模な臨海工業地带の造成に重点を傾斜しすぎ. - 福岡市と北九州, 南, 西九州につながる幹線道路は計 画を再調整し建設, 整備を進めなければならない。

発展方向と提案

- 市が九州開発の拠点となり, 高水準の生活都市を目指 すためには，肥大化より，都市機能充実に施策の重点を 置くべき.

- 第二次産業は行政区域にとらわれず，北九州，西九州 の結節点として機械工業を主軸とする諸工業の広域的内 陸展開を推進することが望ましい. 市域内は重化学のコ ンビナートを期待するより, 既存工業の発展と食料, 機 械などの敵種工業を誘致, 育成すべき。

・第三次産業は産業構造に占める割合が高いが, 卸し, 小売り，サービス業など各業種の実態を検討し，きめの 細かい振興，改善策が必要。
都城市（1962年10月6日1面より連載開始）

市の基本的な課題

市の課題は発展をリードすべき産業のない現状を脱し次 の成長の主役を見つけ出すこと

市の性格

九州縦貫高速自動車道路は，九州中南部の集約酪農地 帯と北九州を結ぶ役割を担うだろう。霧島酪農地帯が背 景の畜産加工, 流通発展を求めるべき。資源型, 労働集 約型工畜を育成し厚い工業生産都市を目指すべき。 都市機能の問題点

都市機能の問題点

市が戦災復興事業を完成させ，土地区画整理，総合運 動公園の建設, 道路整備など努力は高く評価。

最重要路線の宮崎一鹿児島の国道が中心商店街を分断 しているのは問題.

農業振興の姿勢が不確立，営農類型，作目体系の混

乱，農協の小分立が近代化を阻む要因

衛生施設が遅れ結核患者も多い。

未来図と提案

市街地を囲む循環幹線道路の建設，各方面へ至る幹線

道路はこの循環道路から派生させるのが望ましい

·土地利用区分は循環道路の内側を商業・住宅区，外側 を農・工業区とし，工業用地は沖中地区に重点を置き,

地形成し農地と混じらないよう配慮すべき

農地の集団化と用水, 機械体系の整備を急ぎ大型機械 による大規模営農へ移行が必要

製造工業は立地・市場条件からみて資源型企業の育

成, 導入が適当

商工業の零細性を是正，機能強化のため経営の近代

化，共同化を推進必須

\section{北九州市（1963年1月3日4面より連載開始）}

新市の基本的な課題

産業基盤を拡充するばかりでなく，生活，文化の環境 極的に整備することが新市の意義と課題.

新市の性格

市は中央から波及する発展エネルギーを増幅，九州

内，瀬戸内工業の循環体系に浸透させる，心臓部的な役

割をになった生産都市。市の発展は循環体系の確立と相 互交流の強化によってもたらせる。詶については福岡 市と連携し地域開発の中核となるべき。

- 都市機能の混乱，産業基盤の行き詰まり，市民生活の 廃を地域住民の英知に上って解決するモデル都市。

都市的諸施設を計画的，合理的に分散し＼cjkstart市域内 $の$ 各

域には，特性に応じた機能を分担させるべき。

市機能の問題点

民間企業の設備と公共投資の不均衡，生活環境整備の 的れが目立つ。

- 港湾は公共岸壁が少なく，不便. 現奥湾の拡張, 整備 には，広域的視野で機能分担を徹底する必要あり

・旧各市とも公営団住宅などの建設に努めていたが，な 不足.

未来図と提案

・新市に引き継ぐ根幹事業は整理統合してマスタープラ に織り込むべき，計画に含める地域は旧五市にとらわ 筑豊、西瀬户内，大分地区との闑連を考虎し

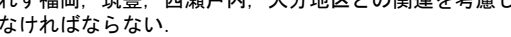
・新市の区は将来のコミュニティ，核の形成に応じ再編 成すべき 成すべき

- 産業構造の面では二次産業の相対的停滞の打開が最大 の課題.

下関市（1963年7月9日7面より連載開始）

\section{市の基本的な課題}

市の課題は, 市発展の原動力をどう作り出すか

の市の性格

市は北九州，瀬戸内工業地帯の発展を背景に工業都市 的な性格を強めようが，外から商業資本が進出してくる ほど客観情勢も内部条件も未熟。

・経済的には北九州と同質化し，生活，文化の面では個 性を主張すべき。市民が高度な生活, 文化を築かなげ ばならない

北九州には生鮮食料品の補給基地，山口県西部地区に は流通，金融の中心，山陰地区には後進地開発の拠点と なるべきである

今後の問題点

一工業, 商業, 農業水産が発展の可能性はあるが, 発展 の主役になりえないのは各部門が別の理論と次元で成育 されてきたため

・市が行政的には山口県，経済的には北九州圏に属する のは，市発展の障害

未来図と提案

約十年後の未来図として多様な産業内容，充実した都 機能を備えた中規模都市を想定

近代的な経営感覚を導入し経営規模の大型化，農協合 併などで近郊農業を確立. 農業, 漁業, 商業発展の障 害, 近代化を急ぐべき

・長府工業地帯の形成には長期的な展望が必要, 性急な 期待はかけず中小企業団地造成により企業の育成にカを 入れるべき
熊本市（1963年10月27日1面より連載開始）

基本的な課題

過去の繁栄の路線に発展方向を求めず，時代に対応する 熊本を築くこと.

市の性格

“近代市民意識と起業精神がつくりだす “市民都市”

キビリタス）を目指すべき. 行政に傾斜しすぎてきた

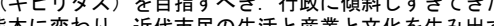
都市の建設.※キビリタス (Civilitas) 市民の権利, 義 務の関係が互いに素直に認められ，保証されている市民 的社会の理想の姿を表現した概念とされている

北九州と南九州の経済連関を強化する中継地点の役割 を果たすべき

今後の問題点

行政に傾斜し発展したため, 重大なひずみが出来てい る. 根本的な打開が急務

・都市づくりの基本的な姿勢を、市民のための都市体系 整備におき，市民が利用する公共施設整備を急がねばな

未来図と提案

10年後の能本市として近代的な市民意識に支えられた 健康な生活と産業のある都市

・マスタープランは諸点について留意すべき

1) 行政に偏った都市の性格を改め, 当面は都市機能，第 二次, 三次産業の拡充, 広域連絡道路整備など産業対策 を重視し，市発展の原動力とする。

2) 土地利用計画を早急に策定する

a. 工業用地は豊肥線以南の平坦部, 住宅地は健軍, 秋津 などの東部台地と新地などの北部台地に集約，機能的て 美しい市街地を形成.

b. 新しいシビックセンターを白川左岸の適地に建設

c. 白川右岸の既成ビジネスセンター、ショッピングセン ターは積極的に再開発。

日田市（1963年11月29日7面より連載開始）

○現段階の意義

広い視野から市の可能性を見極め，産業政策，都市建設 の姿勢を確立すること

市の性格

発展の主軸は製造工業, 副軸は観光. 既存工業の近代 的編成を中核とした内陸産業都市を目指すべき. 観光は 大型広域観光都市ではなく近郊を対象とした観光として ・現代的で機能的な“公園都市”を掲げるべき

後進性の強い地区の開発を促し、開発拠点となるべ

今. 今後の重要課題

主力産業はいずれも転機を迎えているが，危機意識は 希薄, 産業界の近代化意欲が不十分。

- ダム建設，河川改修の促進道路体系を根本的に再編成

・旧市域と合併地域間に, 行政面, 住民意識で断層あ 未来図と提案

約十年後には中北部九州の内陸産業都市，レクリエー ション都市として独自の地位, 役割を持つだろう。

・早急にマスタープランを策定，長期的な諸施策を確定 すべき。計画期間は約十年、重点は、産業政策,都市計

画, 財政運営に置く. 産業政策の焦点は製造工業と観

光. 計画は市民の参加を求め, 国, 県の施策を誘導.

農業の核は酪農，畜産，果樹，地帯区分によって，基

幹作目, 営農類型を明確にし，大型化と近代化流通の合 理化急ぐ

佐賀市 (未確認)

基本的な課題

佐賀市の問題は明確なビジョンを掲げ，前進すること

市の性格

市は四通八達したクリークと社寺仏閣による農村都市 ら脱し, 産業発展

都市”を目指すべき

- 佐賀平坦部，県内における行財政と産業、教育，文化 の各面に指導的役割を果たすべき

市は北九州, 西九州, 不知火・有明・大牟田,の三工 業地帯との産業経済的関連を強める中継地の役割を果た すべき

今後の問題

周辺農村部での発展により，市民性，経済構造などで 格差が生じている。

戦災を受けなかったが近代的な都市の建設を遅らせる 要因となった.

・産業対策は総花的で主体性に欠ける，農業，農水産加 工業を重視し商業発展には考慮すべき。製造工業展開は 適正業種を育成，導入すべき

未来図と提案

約十年後の市は, 近代的市民意識と豊かな所得に支え られ，市民，周辺住民にとけあった都市施設の完備した 福祉都市

・近代的市民意識の目覚めのため都市憲章を制定，都市 建設のため市民運動の展開が必要

- 一次産業は構造改善を推進. 農協の合併，流通機構の 改善を早急に実現すべき

・商店街は高級品，日用品別に分化，再編成するなど機 能分化し，商業構造を改善すべき 
さらに，北九州市においては「九州については福岡市 と連携し地域開発の中核となるべき」「都市的諸施設を 計画的，合理的に分散し，市域内の各地域には，特性に 応じた機能を分担させるべき.『多核都市構想』は機能 の合理的分散を貫いてなく，行政区にこだわらない核の 形成，再編成が，検討される必要あり」とある.

以上より都市診断は, 市域内だけの議論に留まらず周 辺地域との連携を模索するといった「広域的視野」を各 市が有するよう促していたことが特筆すべき点として指 摘できる.

\section{b) 多層スケールにおける都市の位置づけについて}

前節d)に加え, 長崎市では「大村, 諫早市など広域の 都市づくりが必要で，市は中核的な役割を果たさねばな らない」，鹿児島市では「南九州の中核都市として拠点 的な役割果たすことが重要」とあった，さらに，佐賀市 では「北九州, 西九州, 不知火・有明・大牟田の三工業 地帯との産業経済的関連を強める中継地の役割」「市は 都市機能の充実により，佐賀平坦部，県内における行財 政之産業，教育，文化の各面に指導的役割を果たす心゙ き」，北九州市においては「市は中央から波及する発展 エネルギーを増幅させ，九州内，西瀬戸内工業の循環体 系に浸透させる心臟部的な役割をになった生産都市」と の記述が得られた。

以上より都市診断は，九州全域での中心的都市，九州 を北部や南部に分けた場合の中核都市，各県レベルの各 市の役割といった「多層スケールにおける各市の位置づ け」を打ち出そうとしていたことが特筆すべき点として 指摘できる.

\section{4. 都市政策的影響の分析}

\section{(1) 分析方法}

本研究では，西日本都市診断が及ぼした都市政策的影 響を分析するために，各市において策定された総合計画

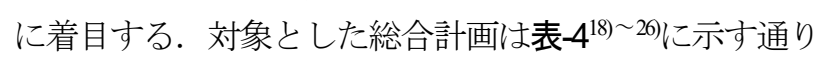
であり，策定年はおおむね衫1960年代中期から70年代初期 であった. 3章で対象とした各都市の都市診断の実施時 期と各都市の総合計画の策定時期を模式的に示したもの が図-2である. 北九州市，熊本市では診断の1〜2年後に 総合計画が策定されており，その他の都市は診断後7〜 10年を経て総合計画の策定に至っていることがわかる. また，診断の新聞記事および総合計画文書等より，都市 診断委員の氏名・所属・専門のリストと各都市への関与 状況を整理した（表-5）。表-4に示した各都市の総合計 画の記述内容を精読し，それを踏まえ，診断結果と総合 計画での記述内容の比較をおこなった.
表-4 対象とした総合計画

\begin{tabular}{|l|l|l|}
\hline & 策定年 & 名称 \\
\hline 福岡市 & 1966 年 & 福岡市総合計画書一基本計画一 \\
\hline 北九州市 & 1965 年 & 北九州市長期総合計画 基本計画 \\
\hline 佐賀市 & 1967 年 & 佐賀市総合計画 \\
\hline 長崎市 & 1970 年 & 長崎市総合計画 \\
\hline 熊本市 & 1964 年 & 熊本市総合計画 \\
\hline 鹿児島市 & 1972 年 & 鹿児島市総合計画 \\
\hline 都城市 & 1971 年 & これからの都城市 総合計画 \\
\hline 日田市 & 1970 年 & 日田市基本構想・基本計画 \\
\hline 下関市 & 1971 年 & 下関市基本計画 \\
\hline
\end{tabular}

\begin{tabular}{|c|c|c|c|c|c|c|c|c|c|c|c|c|c|c|c|}
\hline 年代 & 60 & 61 & 62 & $63 \quad 6$ & \begin{tabular}{l|l}
64 & 65
\end{tabular} & 6 & 67 & \begin{tabular}{l|l}
68 & 6 \\
\end{tabular} & \begin{tabular}{|l|l|}
69 & 70 \\
\end{tabular} & 71 & \begin{tabular}{|l|l|}
72 & 73 \\
\end{tabular} & \begin{tabular}{|l|l|}
74 & 75 \\
\end{tabular} & \begin{tabular}{|l|l}
76 & 7 \\
\end{tabular} & 77 & 78 \\
\hline 䄽用市 & & 第一 & E & & & & 三次祩岡 & 岡市整合 & 合往面 & & & & & & \\
\hline 北九州市 & & & & t) & 北: & 㖄 & 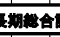 & 部面 & & & & & & & \\
\hline 结算市 & & & & & 3 & & & 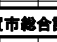 & 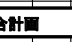 & & & & & & \\
\hline 镸情市 & & & s & & & & & & & 雪露合 & 侖部面 & & & & \\
\hline 觜本市 & & & & 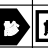 & 显本本市 & 合 & & & & & & & & & \\
\hline 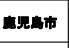 & & & $\mathbf{2}$ & & & & & & & & 鹿児島市能 & 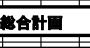 & & & \\
\hline 契敇市 & & & 5 & & & & & & & & 纹耧合部圆 & & & & \\
\hline 旺市 & & & & F & & & & & & 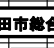 & 合㝇面 & $\eta$ & & & \\
\hline 下地市 & & & & 5 & & & & & & & 市暂合却面 & & & & \\
\hline 全国 & & & 全国: & 整合開 & 䠼针面 & & & & 新全国㮁 & 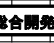 & & & & & \\
\hline
\end{tabular}

図-2 都市診断の時期と総合計画の策定時期

\section{(2) 分析結果}

ここでは，都市診断時における指摘の具体的な内容に 則して, 診断結果と総合計画との記述内容を比較し「市 独自の特徵的事項」と「共通事項」に分けて整理した. すなわち，個別の都市が独自に抱えている課題や性質一 の指摘があるものを「市独自の特徽的事項」に，それ以 外の西日本都市診断全体にわたって提示される共通の話 題ならびに当該市の範囲に収まらず広範囲の地域に関係 する事項を「共通事項」とした．また類似した内容につ いてまとめたものが表-6である.

\section{a) 類似点}

福岡市では「マスタープランは行政区にとらわれ広域 的な視野の展開に乏しい，二次産業の構成比率の低さに より, 事業計画も大規模な臨海工業地帯の造成に重点を 傾斜しすぎ」「福岡市と北九州, 南, 西九州につながる 幹線道路は重要な意義を持つが計画を再調整し投資の順 序を考え早急に建設, 整備を進めなければならない, 北九州では「用水源の開発を進めねばならないが，工業 利用状況に不合理があり都市用水を圧迫している」「新 市の区は将来のコミュニティ, 核の形成に応じ再編成す べき」「商業の比重は, 高めていく必要あり, 卸し, 小 売りを通じる商業組織を拡充, 高度化し, 周辺購買力吸 収に努める必要あり」, 佐賀市では「市は四通八達した クリークと社寺仏閣による農村都市から脱し, 産業発展 
と近代市民意識による『豊かな福祉都市』を目指すべき」

「新しい都市建設では歴史的，文化的遺産の保存に留意 すべき」との記述において診断結果と総合計画の内容が 類似していることが明らかとなった。

また，長崎市では「市だけを取り上げれば観光を含め た第三次産業に期待」「過度密集地帯の再開発は防災上 からもきわめて重要な問題」「水資源は西彼，大村，諫 早を含め広域的に開発, 地域に応じた配水計画を立て る」，熊本市では「水害，火災などの防災対策は都市建 設の前提課題. 災害を繰り返している河川の用排水には 根本的改善策をたてるべき」「農協の合併，流通機構の 改善を早急に実現する必要あり」, 鹿児島市では「市と 周辺は観光地として脚光を浴びはじめた. 問題は多いが 観光都市として発展を目指すことは妥当」「都市計画， とくに道路，港湾，土地造成，住宅対策については，市 の今後の性格と使命に沿い根本的な補正が必須」との記 述で類似した.

さらに，都城市では「農業振興の姿勢が不確立，営農 類型，作目体系の混乱，農協の小分立が，近代化を阻む 要因」「農地の集団化と用水, 機械体系の整備を急ぎ大 型機械による大規模営農へ移行が必要」「商工業の零細 性を是正，機能強化のため経営の近代化，共同化の推進 が必須」, 日田市では「観光は大型広域観光都市ではな く近郊を対象とした観光として期待」「主力産業はいず れも転機を迎えているが，危機意識は希薄，産業界の近
代化意欲が不十分」「農業の核は畜産，果樹，地帯区分 によって, 基幹作目, 営農類型を明確にし, 大型化と近 代化流通の合理化急ぐ」，下関市では「教育，文化の振 興に力を注ぎ近代的市民を育てなければならない」「長 府工業地带の形成には長期的な展望が必要」「商業経営 の近代化に努めるべき」との記述において類似している ことが把握された.

以上より, 程度の差は認められるものの「診断結果」 と総合計画の間において類似する内容が確認された.

\section{b) 相違点}

長崎市の住宅施策において，診断結果では「長崎市外 の地域をも視野に入れた形での住宅地整備」が謳われた のに対し, 総合計画では「長崎市内での住宅地整備」に 言及が留まっていることが把握された．また，日田市に おける観光戦略において, 診断結果では「北部九州を観 光圈」と捉えるのに対し, 総合計画では「九州全体を観 光圈」と捉える言及があった．このように，住宅地整備 や観光戦略そのものの方向性は一致しているものの，そ の対象とする規模や範囲の面で, 診断と総合計画での見 解の相違が認められた.

\section{c) 都市診断委員と総合計画審議委員の比較}

都市診断委員が，総合計画策定について議論する立場 にあった審議委員として参画したか娝かについて調査し た結果は表-5中に「○」と「○」で示した.これより, 磯村，内藤，都留，光吉，神崎の5名はほぼ全てにおい

表-5 都市診断委員の構成と総合計画審議委員との重複の有無 (所属は当時)

\begin{tabular}{|c|c|c|c|c|c|c|c|c|c|c|c|c|c|c|}
\hline $\begin{array}{l}\text { ○は総合計 } \\
\text { 画審議委員 } \\
\text { との重複を } \\
\text { 表す } \\
\text { ○は都市診 } \\
\text { 断委員のみ } \\
\text { を表す }\end{array}$ & $\begin{array}{l}\text { 磯東 } \\
\text { 村京 } \\
\text { 英都 } \\
- \text { 立 } \\
\frown \text { 大 } \\
\text { 都学 } \\
\text { 市教 } \\
\text { 社授 } \\
\text { 会 } \\
\text { 学顧 } \\
\text { 問 }\end{array}$ & $\begin{array}{l}\text { 内九 } \\
\text { 藤州 } \\
\text { 莞大 } \\
\text { 爾学 } \\
\text { 教 } \\
\text { 社授 } \\
\text { 会 } \\
\text { 学 }\end{array}$ & $\begin{array}{l}\text { 都九 } \\
\text { 留州 } \\
\text { 大大 } \\
\text { 治学 } \\
\text { 助 } \\
\text { 経教 } \\
\text { 済授 } \\
\text { 学 }\end{array}$ & $\begin{array}{l}\text { 光九 } \\
\text { 吉州 } \\
\text { 健大 } \\
\text { 次学 } \\
\text { 助 } \\
\text { 建教 } \\
\text { 築授 } \\
\text { 学 }\end{array}$ & $\begin{array}{l}\text { 神九 } \\
\text { 崎州 } \\
\text { 義都 } \\
\text { 夫市 } \\
\text { 学 } \\
\text { 経会 } \\
\text { 済常 } \\
\text { 史任 } \\
\text { 理 } \\
\text { 事 }\end{array}$ & $\begin{array}{l}\text { 鳥九 } \\
\text { 居州 } \\
\text { 健経 } \\
\text { 男済 } \\
\text { 調 } \\
\text { 経査 } \\
\text { 済協 } \\
\text { 政会 } \\
\text { 策理 } \\
\text { 事 } \\
\text { 長 }\end{array}$ & 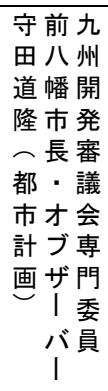 & $\begin{array}{l}\text { 平佐 } \\
\text { 野賀 } \\
\text { 義大 } \\
\text { 隆学 } \\
\text { 教 } \\
\text { 財授 } \\
\text { 政 } \\
\text { 学 }\end{array}$ & $\begin{array}{l}\text { 河 長 } \\
\text { 地崎 } \\
\text { 貫 } \\
\text { 一学 } \\
\text { 教 } \\
\text { 経授 } \\
\text { 济 } \\
\text { 地 } \\
\text { 理 }\end{array}$ & $\begin{array}{l}\text { 有熊 } \\
\text { 田本 } \\
\text { 一大 } \\
\text { 郎学 } \\
\text { 助 } \\
\text { 経教 } \\
\text { 済授 } \\
\text { 学 }\end{array}$ & $\begin{array}{l}\text { 岩鹿 } \\
\text { 本児 } \\
\text { 和島 } \\
\text { 秋大 } \\
\text { 学 } \\
\text { 経教 } \\
\text { 済授 } \\
\text { 学 }\end{array}$ & $\begin{array}{l}\text { 上宮 } \\
\text { 野崎 } \\
\text { 登大 } \\
\text { 学 } \\
\text { 経教 } \\
\text { 済授 } \\
\text { 地 } \\
\text { 理 }\end{array}$ & $\begin{array}{l}\text { 武大 } \\
\text { 石分 } \\
\text { 勉大 } \\
\text { 学 } \\
\text { 経教 } \\
\text { 済授 } \\
\text { 政 } \\
\text { 策 }\end{array}$ & $\begin{array}{l}\text { 岡山 } \\
\text { 倉口 } \\
\text { 伯大 } \\
\text { 士学 } \\
\text { 教 } \\
\text { 経授 } \\
\text { 済 } \\
\text { 学 }\end{array}$ \\
\hline 福岡市 & 0 & 0 & 0 & 0 & 0 & 0 & & & & & & & & \\
\hline 北九州市 & 0 & 0 & 0 & 0 & 0 & 0 & 0 & & & & & & & \\
\hline 佐賀市注 1 & & & 注 3 & 注 3 & 注 3 & & & $0^{\text {注 } 2}$ & & & & & & \\
\hline 長崎市 & 0 & 0 & 0 & 0 & 0 & & & & 0 & & & & & \\
\hline 熊本市 & 0 & 0 & 0 & 0 & 0 & & & & & 0 & & & & \\
\hline 鹿児島市 & 0 & 0 & 0 & 0 & 0 & & & & & & 0 & & & \\
\hline 都城市 & O & 0 & O & 0 & 0 & & & & & & & 0 & & \\
\hline 日田市 & 0 & 0 & 0 & 0 & 0 & & & & & & & & 0 & \\
\hline 下関市 & 0 & 0 & 0 & 0 & 0 & & & & & & & & & 0 \\
\hline
\end{tabular}

注 1 : 佐賀市については新聞記事が未収集のため都市診断委員が不明である

注 2 :「都市診断西日本篇」により補完した

注 3 : 少なくとも総合計画審議委員であることが確認できた 
て都市診断委員として関与していることが分かる。なお， 都市診断に関わった有識者は，都市計画，土木や建築以 外に，社会学や経済学，政策学等に及んでいることから， 診断は学際的・分野横断的に展開されていたと考えられ る. さらに，福岡市と北九州市においては，総合計画審 議委員とも重複している。一方で，それ以外の都市にお いては，各地方の有識者が診断委員として必ず加入して おり，佐賀市，熊本市，鹿児島市においては総合計画審
議委員とも重複していることが把握された，他方，長崎 市，都城市，日田市，下関市については，診断委員と総 合計画審議委員に重複は見られなかった。

以上のように，診断委員と総合計画審議委員が重複し ていることによって, 診断結果が総合計画策定の議論に 積極的に取り入れられたことが推察できる. 一方で，長 崎市，都城市，日田市，下関市のように診断委員と総合 計画審議委員の重複が見られなかった場合でも, 前項ま

表-6 診断結果と総合計画との記述内容の比較

\begin{tabular}{|c|c|c|c|}
\hline & 鹿児島市 & 都城市 & 熊本市 \\
\hline $\begin{array}{l}\text { 市 } \\
\text { 独 } \\
\text { 自 } \\
\text { の } \\
\text { 特 } \\
\text { 徵 } \\
\text { 的 } \\
\text { 事 } \\
\text { 項 }\end{array}$ & $\begin{array}{l}\text { ·国際観光保養都市ビジョンを策定, 特色ある南九州観 } \\
\text { 光の体系的, 広域観光ルートの確立, 個性ある観光 } \\
\text { コース開発を図る } \\
\text { ·住宅数が不足 } \\
\text { ·食料品製造, 木材加工, 资源立地型の一次加工の工業 } \\
\text { が大きな比率を占めている } \\
\text { ·機械, 金属化学工業など付加価値型の二次加工の工業 } \\
\text { か增える傾向にある }\end{array}$ & 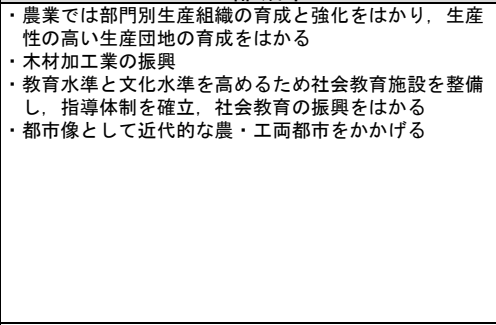 & 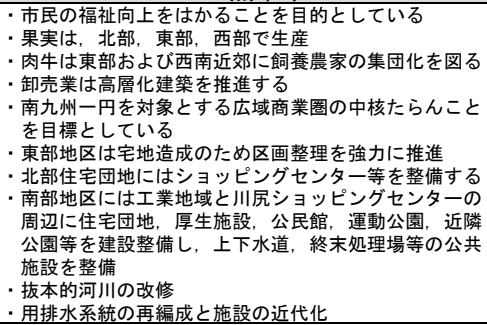 \\
\hline $\begin{array}{l}\text { 共 } \\
\text { 通 } \\
\text { 事 } \\
\text { 項 }\end{array}$ & 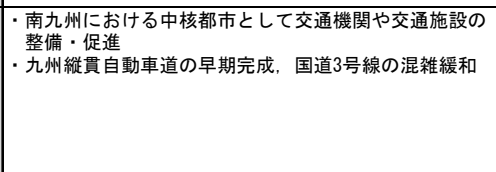 & $\begin{array}{l}\text { ·これからの農業の中心は農業経営に尃念する企業的農 } \\
\text { 業経営でなければならない } \\
\cdot \text { 大型機械と経営を密着させた大型農業が展開されなけ } \\
\text { ればならない } \\
\cdot \text {-工業では中小企業の協業化，合同化，協同化 } \\
\cdot \text { 個々の商店の経営の合理化，近代化，合同化を促進 } \\
\cdot \text { 魅力ある商店街形成のため既成商店街の再開発 }\end{array}$ & $\begin{array}{l}\cdot \text { 農業経営の協業共同化を促進 } \\
\cdot \text { 農業団体の組織の合理化 } \\
\cdot \text { 流通機構の変化に対応するために系列化, 組織化をす } \\
\text { すめ, 小壳商店の大型化をはかる }\end{array}$ \\
\hline & 長崎市 & 北九州市 & 日田市 \\
\hline $\begin{array}{l}\text { 市 } \\
\text { 独 } \\
\text { 自 } \\
\text { 特 } \\
\text { 徵 } \\
\text { 的 } \\
\text { 事 } \\
\text { 項 }\end{array}$ & 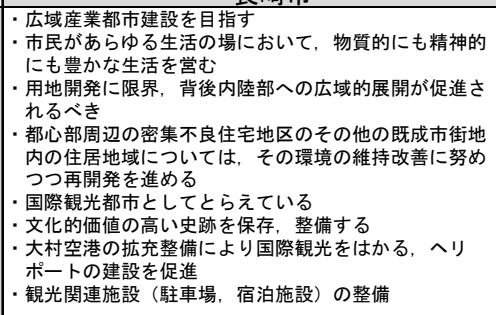 & 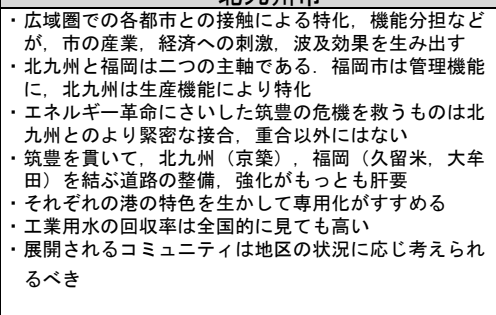 & $\begin{array}{l}\text { ·地域の特性に合った特徵ある適地作目への移行と, } \\
\text { 主産地の形成を推進 } \\
\text { ·駐車難を解消するた駐車場の設置を促進 }\end{array}$ \\
\hline $\begin{array}{l}\text { 共 } \\
\text { 通 } \\
\text { 事 } \\
\text { 項 }\end{array}$ & 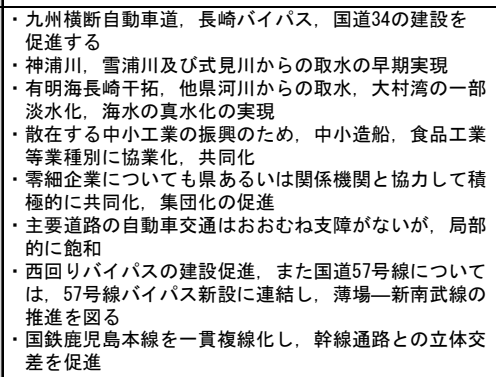 & $\begin{array}{l}\text { 筑後川からの導水をはかる } \\
\text { ・旧商店街を再開発し，その立体化，稠密化，美化をは } \\
\text { かる } \\
\text { ·商店の経営, 財務, 労務の近代化，組織化をすすめる }\end{array}$ & 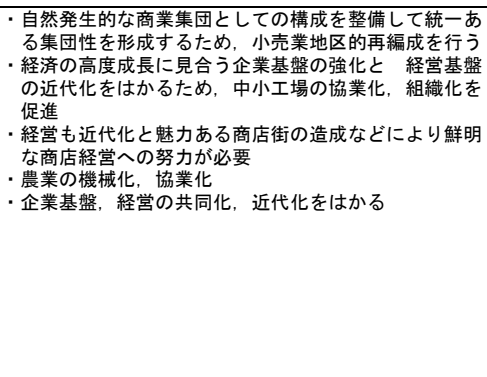 \\
\hline & 福岡市 & 下関市 & 佐賀市 \\
\hline $\begin{array}{l}\text { 市 } \\
\text { 独 } \\
\text { 自 } \\
\text { 特 } \\
\text { 徵 } \\
\text { 的 } \\
\text { 事 } \\
\text { 項 }\end{array}$ & 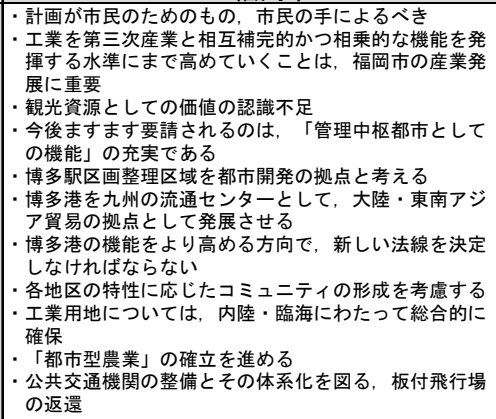 & 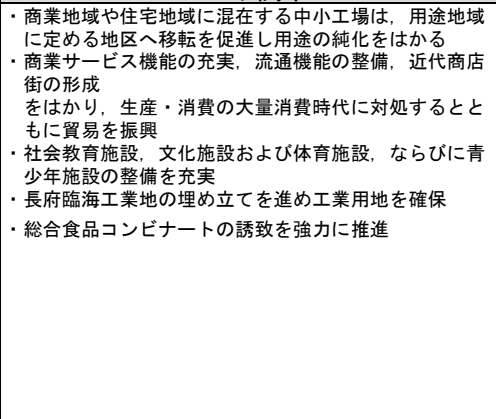 & 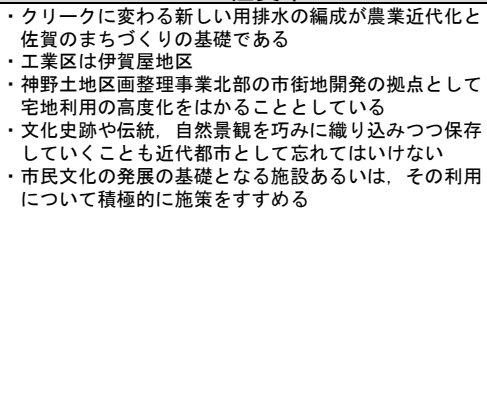 \\
\hline $\begin{array}{l}\text { 共 } \\
\text { 通 } \\
\text { 事 } \\
\text { 項 }\end{array}$ & 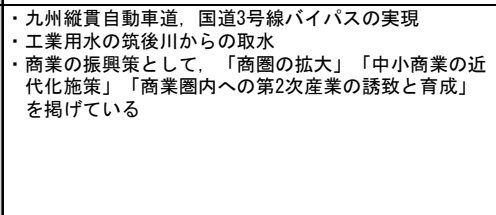 & $\begin{array}{l}\text { ·農業の技術的側面からの努力と, 経営規模拡大など農 } \\
\text { 業経営の合理化をはかる } \\
\text { 中小企業については協業化，共同化を促進，企業構造 } \\
\text { の高度化 } \\
\text { ·卸売業および小売り事業の体質改善，経営の近代化と } \\
\text { 合理化 } \\
\text { 中心商店街の整備 }\end{array}$ & 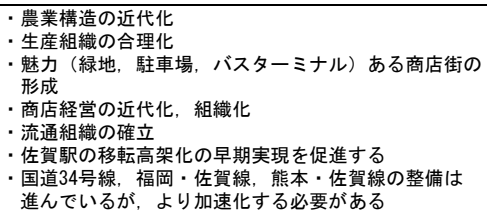 \\
\hline
\end{tabular}


でで述べたように「診断結果」と総合計画の間で記述内 容に類似点が認められたことを鑑みると，新聞報道を通 じて「都市診断」の結果が広く市民に周知されていた事 実が少なからず総合計画策定に影響を与えていたと推察 できる.

\section{5. 総合的考察}

\section{(1) 1960年代の計画にかかわる議論における西日本都 市診断の位置づけ}

ここでは，本研究を通して把握されたこととして， 1960年代の計画にかかわる議論における西日本都市診断 の位置づけについて考察する．2章で述べたように，全 総は長期的かつ広域的な計画であるが故に不確定性を除 去することはできない抽象的なものであり，一方で各市 の策定する総合計画は一般的に画一的で地域の問題に即 した内容に成り得ていない状況であるとの指摘があった しかし，これまでに述べたとおり，都市診断は「広域的 な視野」や「多層スケールにおける都市の位置づけ」と いった特筆すべき要点を有しており，個別具体的な診断 を経て各市の特色をあぶりだしたうえで，九州地域の全 体像および各市のその地域全体における役割や位置づけ を相対的に検討寸る試みであったといえる.

すなわち，西日本都市診断は全総や総合計画における 論点に対して，それらを補完する役割を担ったと捉える ことができ，ここに1960年代の計画にかかわる議論にお ける西日本都市診断の位置づけを見出すことができる.

\section{（2）西日本都市診断の特徵と役割}

まず，3章で指摘したとおり，西日本都市診断は市域 内だけの議論に留まらず周辺地域との連携を模索すると いった「広域的視野」を各市が有するよう促していたこ と, さらに九州全域から各県内に至る「多層スケールに おける各市の位置づけ」を打ち出そうとしていたこと, の2点の特徴を有すると考えられる.

次に，4章で指摘したとおり，各都市の診断結果と総 合計画では多くの点で類似点が把握されている.このこ とから, 都市診断によって指摘された都市の課題や各都 市の目指すべき方向性を参照しながら，その後の総合計 画が審議されたことが推察される，そのつながりを示す 状況証拠的な根拠として, 本研究では診断委員と総合計 画審議委員の構成メンバーの重複を指摘した. 一方で, 診断委員と総合計画審議委員が必ずしも一致しない場合 も認められたことから，往時の新聞といら媒体のもつ都 市政策への影響が大きかったことも指摘できる.

さらに，西日本都市診断の実施された時期は1960年代 であり，国土計画の基礎づくりや基礎自治体における将
来像を模索し始めた時期と符号する. 加えて, 今回の対 象都市においては，診断後概衫10年以内で総合計画が策 定されていることを把握した. これらのことから，西日 本都市診断は総合計画を策定するための「参考資料」と しての役割を担ったと考えられる.

\section{6. おわりに}

\section{(1) 本研究の成果}

本研究では, 往時の都市診断において何が議論され, それらの診断がその後の都市政策に及ぼした影響につい て分析することを通して，都市診断の特徵とその役割， ならびに1960年代の計画における位置づけについて考察 した.

その結果，1960年代の計画にかかわる議論における西 日本都市診断の位置づけとして全総や総合計画における 論点を補完する役割を担ったこと，都市診断は「広域的 視野」を各市が有するよう促していたこと，「多層スケ 一ルにおける各市の位置づけ」を明確化したこと，を指 摘した. また，診断委員と総合計画審議委員の重複や内 容の類似点等についての分析から往時の新聞という媒体 のもつ都市政策への影響を指摘した. さらに, 都市診断 が総合計画を策定するための「参考資料」の役割を担つ たことも指摘した.

\section{(2) 今後の課題}

今後は, 残りの12都市に関しても要点の抽出を行い 「診断結果」以外の項目にも焦点を当て，より精緻な分 析を行う必要がある. また, 都市診断による診断結果が 実際に各都市のその後の発展方向とどの程度合致してい るのか追跡調查をすることも有意義である，一方で，都 市診断を実施した新聞社に着目し，往時のマスメディア と都市政策の関連性について議論することも本研究の成 果の深化につながると考えられる.

付言として，都市診断の分析を透かして現れてくる往 時の都市論あるいは都市計画にかかわる技術論について 言及したい. 都市を診断するとは，必ずしも定量的な検 討だけではなく，定性的な議論も多かった．また，診断 は都市計画，土木や建築以外に，社会学や経済学，政策 学等に及び，学際的・分野横断的に展開していた. これ らの往時の都市論や都市計画技術論について，より詳細 な検討をおこなうことで今日の都市計画に対して示唆を 得る可能性があるのではないだろうか.

謝辞 : 本研究は, 公益財団法人大林財団の研究助成によ りおこなったこと，また各市関係機関から資料提供等の ご協力をいただいたこと, さらに查読者の方から有益な 
ご示唆をいただいたこと，これらに対しここに記して感 謝の意を表します。

\section{参考文献}

1) 小山陽一郎：全国総合開発計画とはなんであったの か【前編】，土地総合研究，Vol. 19, No. 2, pp. 18-33, 2011.

2) 蓑原敬 : 今, 何故 1960 年代を問題にするのか? , 日 本都市計画学会「284 都市計画」, Vol. 59, No. 2, p. 3, 2010.

3) 西日本新聞社: 1962 年 4 月 17 日から 1963 年 12 月 4 日にかけての都市診断記事.

4) 西日本新聞社編 : 都市診断西日本篇, 1966.

5) 佐野浩祥, 十代田朗 : 過去 20 年間におけるわが国の国土 計画に関する言説の変遷一国会議事録を対象として一, 都市計画論文集，No. 38-3,pp. 187-192,2003.

6) 三上訓顯，坂本淳二 : 総合計画における副都心施策と実 態に関する考察，都市計画論文集，No. 34,pp. 115-120, 1999.

7) 福原由美，鈴木浩：地方自治体における政策形成に関す る考察一地方自治体の総合計画策定過程から一, 都市計 画論文集，No. 37,pp. 277-282,2002.

8) 田中皓介, 藤井聡 : 1950 年代から現代までの公共事業を 巡る新聞社説についての時系列分析，土木学会論文集 D3, Vol. 71, No. 5,pp. I 143-I 149, 2015.

9) 原口征人, 今尚之, 佐藤馨一 : 新聞資料おける小樽港防
波堤建設事業と水面埋立事業の経緯，土木史研究論文集， No. 17,pp. 295-304, 1997.

10) 石橋知也, 柴田久：1960 年代の福岡市政の変遷にみ る都市戦略のあり方に関する史的考察，土木学会論 文集 D1，Vol. 70, No. 1, pp. 1-15, 2014.

11) 前掲 1), p. 19

12) 藤井聡 : 改訂版 土木計画学 公共選択の社会科学, p. $34,2018$.

13）前掲 7),p. 277

14）西日本新聞社: 西日本新聞百二十年史, pp. 209-210, 1997.

15）前掲 4),pp. 13-34

16) 前掲 4),pp. i-ii

17) 前掲 4),pp. 191-222

18）福岡市総合計画書一基本計画一, 1966.

19）北九州市長期総合計画 基本計画， 1965.

20）佐賀市基本計画，1967.

21）長崎市総合計画， 1970.

22) 熊本市総合計画, 1964.

23）鹿児島市総合計画, 1972.

24）これからの都城市 総合計画, 1971.

25）日田市基本構想 - 基本計画, 1970.

26）下関市基本計画，1971.

(Received June 21, 2019)

(Accepted January 14, 2020))

\section{A CONTENT ANALYSIS OF "WEST JAPAN URBAN DIAGNOSIS" CONDUCTED IN THE 1960S AND ITS URBAN POLICY IMPACT}

\section{Masayuki TSUTSUI and Tomoya ISHIBASHI}

The subject of this research is "West Japan urban diagnosis". It was implemented by The Nishinippon Shimbun Co., Ltd. in 1962-65 with the cooperation of urban experts. In this case, nine out of 21 cities are taken as an example. The purpose of this study is to analyze the contents of the discussion in the urban diagnosis in the past and to consider the influence that the diagnosis has on the urban policy after that. The research results are shown below. It became clear that the role of the Western Japan city diagnosis in the discussions related to the plans in the 1960s played a role to complement the issues in the comprehensive national development plan in 1962 and masterplan. The characteristic of urban diagnosis is that it promoted the wide-area view to each city, and clarified the positioning of each city on the scale from Kyushu to each prefecture. From the analysis of the overlap between the diagnosis committee members and the masterplan deliberation committee members and the similarities of the contents, we pointed out the influence on the city policy of the past newspaper media. It was also pointed out that the city diagnosis played the role of "reference document" for formulating a masterplan. 